\title{
Nitrogen Fertilization of Sorghum in an Oxisol in Northwestern Puerto Rico ${ }^{1,2}$
}

\author{
A. Sotomayor-Ríos and M. A. Lugo-López $z^{3}$
}

\begin{abstract}
The effect of rate and timing of $\mathrm{N}$ applications on yield, nutrient uptake, and other characteristics was studied in grain sorghum grown on an Oxisol in northwestern Puerto Rico. Studies of the soil nutrient status revealed a $30 \% \mathrm{Al}$ saturation and rather low $\mathrm{Ca}, \mathrm{Mg}$, and $\mathrm{K}$ levels. Leaf $\mathrm{N}$ content was significantly lower in plants from unfertilized than from fertilized plots. Significant differences by treatment were also noted for leaf content of $\mathrm{P}, \mathrm{K}, \mathrm{Ca}$, and $\mathrm{Mn}$, but no consistent pattern could be detected. Flowering was significantly delayed in plants not given $N$. Threshing percentage was not affected by $N$ treatments. Crude protein levels in the grain were higher with split applications of $\mathrm{N}$ than with single applications. The Capó fertilizer-yield equation fit the grain yield data fairly well and could be used to predict yields from the amount of $\mathrm{N}$ fertilizer applied. Near maximum yields were obtained with applications of fertilizer $N$ at $56 \mathrm{~kg} / \mathrm{ha}$. In some cases, more than $70 \%$ of the fertilizer $\mathrm{N}$ was recovered.
\end{abstract}

\section{INTRODUCTION}

Grain sorghum [Sorghum bicolor (L.) Moench] is a valuable source of food for humans and livestock. It is one of the principal cereal crops of the world, subordinate only to wheat, rice, and corn. Sorghum production in Latin America is steadily increasing. Argentina and Mexico, for instance, are among the countries in which sorghum production has increased substantially during the past decade. In 1975 more than 3.5 million ha of grain sorghum were planted in Argentina and more than 1.2 million ha were planted in Mexico (7).

In the humid tropics, Oxisols are highly weathered and very extensive soils. In many of these soils, sorghum is grown for food, but yields are low. The low yields are due in part to the often extreme acidity and relative infertility of these soils. Although sorghum can be grown under generally adverse soil, climatic, and management conditions, even a slight increase in grain yield would benefit many people, especially in the less developed countries.

There is substantial evidence in the literature that yields of various crops, such as corn and sweet potatoes, grown in Oxisols, can be signifi-

${ }^{1}$ Manuscript submitted to Editorial Board December 15, 1977.

${ }^{2}$ Joint contribution form the Mayagüez Institute of Tropical Agriculture, ARS, USDA, Mayagüez, P.R.; the Department of Agronomy, Cornell University, Ithaca, N.Y.; and the Agricultural Experiment Station, University of Puerto Rico, Mayagüez Campus, Mayaguez, P.R. This study was supported in part by ARS and in part by USAID under research contract ta-c-1104.

${ }^{3}$ Research Geneticist, Mayagüez Institute of Tropical Agriculture, ARS, USDA, Mayagüez, P.R., and Professor-Soil Scientist (Ret.), Agricultural Experiment Station, University of Puerto Rico, Río Piedras, P.R., now Consultant, Cornell University, Ithaca, N.Y. 
cantly increased by proper fertilization and proper soil and crop management $(1,5,9,10)$.

The high cost of fertilizer requires that it be used properly, especially if $\mathrm{N}$ is the limiting factor for maximum economic yield, as it generally is with sorghum and other cereal crops. Because the importance of sorghum is increasing steadily in the tropics, efficient management systems that might provide higher crop yields at low levels of $\mathrm{N}$ fertilization should be sought.

This study was designed to evaluate the effect of various $\mathrm{N}$ levels and time of their application on production of a high-yielding grain sorghum hybrid grown on an Oxisol in northwestern Puerto Rico.

\section{MATERIALS AND METHODS}

The experiment was conducted on a Coto soil, a Tropeptic Haplorthox, clayey, kaolinitic, isohyperthermic (6), at the Isabela experimental farm of the Mayagüez Institute of Tropical Agriculture (MITA), ARS, USDA, in northwestern Puerto Rico. The farm is $128 \mathrm{~m}$ above sea level. Its mean annual temperature ranges from $18^{\circ}$ to $31^{\circ} \mathrm{C}$, and the mean annual rainfall is about $1,658 \mathrm{~mm}$. Evaporation from a Class-A pan is about 6 $\mathrm{mm}$ /day during the summer, and $4 \mathrm{~mm}$ /day during the winter.

Before planting, soil samples for chemical analysis were taken at depths of $0-25 \mathrm{~cm}$ and $25-50 \mathrm{~cm}$ at three sites within the experimental field (2). The $\mathrm{pH}$ was determined electrometrically $\left(\right.$ Beckman $^{4}$ expandomatic $\mathrm{pH}$ meter); P by the Bray No. 2 method; $\mathrm{N}$ by the Kjeldahl method; organic matter by potassium dichromate titration; $\mathrm{Ca}, \mathrm{Mg}$, and $\mathrm{K}$ by leaching with $\mathrm{NH}_{4} \mathrm{OAc}$ and using a Hitachi-Perkin Elmer flame photometer; exchangeable $\mathrm{Al}$ by extraction with $1 N \mathrm{KCl}$ and titration (2); and $\mathrm{Mn}$, colorimetrically, using sodium periodate. A bird-resistant sorghum, DeKalb hybrid BR-63, was planted on May 15, 1975, at a seeding rate of about $8 \mathrm{~kg} / \mathrm{ha}$, using a partially incomplete block design with 11 treatments and 5 replications. Each plot consisted of four rows $6 \mathrm{~m}$ long spaced $101 \mathrm{~cm}$ apart. A $4-\mathrm{m}^{2}$ area of each plot from the two inner rows was used for sampling.

Control plots were not given N. All other plots were given ammonium sulfate at rates ranging from 56 to $280 \mathrm{~kg}$ of $\mathrm{N} / \mathrm{ha}$. In treatments 2 to 6 , all $\mathrm{N}$ was banded at planting $(56,112,168,224$, and $280 \mathrm{~kg}$ of $\mathrm{N} / \mathrm{ha}$ ); in treatments 7 to 11 , half of the $\mathrm{N}$ was banded at planting, and half was banded 30 days later. All plots were given a blanket application of $112 \mathrm{~kg}$ of $\mathrm{P} / \mathrm{ha}$ as triple superphosphate and $448 \mathrm{~kg}$ of $\mathrm{K} / \mathrm{ha}$ as chloride. No lime was applied.

${ }^{4}$ Trade names are used in this publication solely for the purpose of providing specific information. Mention of a trade name does not constitute a guarantee or warranty of equipment or materials by the Agricultural Experiment Station of the University of Puerto Rico or an endorsement over other equipment or materials not mentioned. 
Immediately after planting, the herbicide propazine [2-chloro-4,6-bis (isopropylamino)-s-triazine] was applied to all plots at a rate of about 2.5 $\mathrm{kg}$ of active ingredient/ha. Sprinkler irrigation was applied as necessary to provide adequate moisture for the duration of the experiment. Grain and stover $\mathrm{N}$ were determined by the micro-Kjeldahl method using a Technicon Autoanalyzer.

The following data were obtained: 1) number of days from planting to midflower (MF) (visual estimate); 2) number of heads per $4 / \mathrm{m}^{2}$ plot $(\mathrm{h} / \mathrm{p})$; 3) threshing percentage as weight of threshed grain/weight of unthreshed grain $\times 100$ (TP), (determined on the yield sample); 4) weight of 25 dry heads; (5) grain yield at $14 \%$ moisture (GY) (determined from the $4 / \mathrm{m}^{2}$ harvest plot); 6) green and dry weight of stover (grain removed); 7) $\mathrm{N}$ content of grain and stover; and 8) chemical content (N, P, K, Ca, $\mathrm{Mg}, \mathrm{Mn}$ ) of whole leaves collected from two plants/plot on July 16, 1975 (when plants were 2 months old). $\mathrm{N}$ was determined by the microKjeldahl method using a Technicon Autoanalyzer (8); P by the method of Fiske and Subbarow (4); K, Ca, and $\mathrm{Mg}$ by digesting with nitric and perchloric acids and using a flame photometer; and $\mathrm{Mn}$ by colorimetry.

\section{RESULTS AND DISCUSSION}

Selected chemical properties of the Coto clay soil at the experimental site are listed in table 1. The soil is strongly acid and very low in cation exchange capacity. Organic matter levels decrease with depth. Al saturation increases with depth from less than $22 \%$ in the topsoil to $30 \%$ in the subsoil. These data agree with those reported by Fox et al. (5) for Coto clay. Such Al levels should not limit root growth even in Al-sensitive crops such as sorghum. (The almost $60 \% \mathrm{Al}$ saturation observed in Ultisols (5) can limit root growth in sensitive crops.)

The Coto clay soil is relatively low in $\mathrm{Ca}, \mathrm{Mg}$, and $\mathrm{K}$, as has also been reported by other workers (5). The $\mathrm{Mn}$ level is not toxic to plants at this particular experimental site. In spite of its relatively low level, Ca accounts for more than $45 \%$ of the exchangeable cations.

Leaf $\mathrm{N}$ content in 2-month-old sorghum plants ranged from 2.82 to $4.25 \%$ (table 2 ) and was significantly lower in treatment $1(0 \mathrm{~N})$ than in any other treatment. Leaf $\mathrm{N}$ was significantly higher at the highest level of fertilizer $N(280 \mathrm{~kg} / \mathrm{ha}$ ), whether used all at planting or in split applications, than with the lowest level of $\mathrm{N}(56 \mathrm{~kg} / \mathrm{ha})$ applied all at planting. Leaf $\mathrm{N}$ was also significantly higher with split applications of fertilizer $\mathrm{N}$ at $224 \mathrm{~kg} / \mathrm{ha}$ than with application of $\mathrm{N}$ at $56 \mathrm{~kg} / \mathrm{ha}$ all at

\footnotetext{
${ }^{5}$ Riera, A., and Rivera-Núñez, J., La automatización aplicada a los análisis químicos para eł diagnóstico foliar. Central Analytical Lab. Agric. Exp. Stn. Univ. P.R., Mimeographed Report (Undated).
} 
planting. Significant differences by treatment were also noted for leaf content of $\mathrm{P}, \mathrm{K}, \mathrm{Ca}$, and $\mathrm{Mn}$, but no consistent pattern could be detected.

Days to midflower ranged from 67.3 to 75.1 (table 3). Flowering was significantly delayed when no $\mathrm{N}$ was applied. Number of heads/plot ranged from 86.1 to 110.6 , and only the difference between these extreme values was significant. The largest number of heads/plot was observed with treatment 9 (split application of $\mathrm{N}$ at $168 \mathrm{~kg} / \mathrm{ha}$ ). Threshing percentage ranged from 70.0 to $74.4 \%$, but no significant differences were observed among the 11 treatments. Weight of 25 heads ranged from 805 $(0 \mathrm{~N})$ to $1,116 \mathrm{~g}$ ( $280 \mathrm{~kg}$ of $\mathrm{N} / \mathrm{ha}$ ). Only with treatments 3,7 , and 9 was the weight of 25 heads significantly superior to that of treatment 1; the remaining differences were nonsignificant.

Grain crude protein (CP) content ranged from 10.29 to $13.63 \%$. The highest $\mathrm{CP}$ content was observed with split applications of the maximum

TABLE 1.-Selected chemical properties of the Coto clay soil (Oxisol) at the experimental site, Isabela, Puerto Rico

\begin{tabular}{|c|c|c|}
\hline \multirow{2}{*}{ Property } & \multicolumn{2}{|c|}{ Mean value at indicated sample depth } \\
\hline & 0 to $25 \mathrm{~cm}$ & 25 to $50 \mathrm{~cm}$ \\
\hline Cation exchange capacity (meq/100 g) & 5.0 & 5.1 \\
\hline $\mathrm{pH}$ & 5.0 & 4.6 \\
\hline$P(p / m)$ & 44.8 & 8.8 \\
\hline$N(\%)$ & .1 & .1 \\
\hline Or£ inic matter (\%) & 2.8 & 1.3 \\
\hline $\mathrm{Al}^{3+},(\%$ saturation $)$ & 22 & 30 \\
\hline \multicolumn{3}{|l|}{ Exchangeable cations (meq/100 g) } \\
\hline $\mathrm{Ca}^{2+}$ & 2.3 & 1.5 \\
\hline $\mathrm{Mg}^{2+}$ & 1.3 & 1.1 \\
\hline $\mathrm{K}^{+}$ & .2 & .1 \\
\hline $\mathrm{Mn}^{4+}$ & 1 & .4 \\
\hline
\end{tabular}

quantity of $\mathrm{N}$ used ( $280 \mathrm{~kg} / \mathrm{ha})$. This observation suggests that for grain $\mathrm{CP}$ content, split applications of $\mathrm{N}$ are more effective than single application of the same total amount of N. Grain yield ranged from 4,504 to $6,884 \mathrm{~kg} / \mathrm{ha}$. No significant differences in yield were measured among $\mathrm{N}$ treatment levels ranging from 56 to $280 \mathrm{~kg} / \mathrm{ha}$, but yields from all these treatments were significantly higher than that obtained without $\mathrm{N}$. With $\mathrm{N}$ at $56 \mathrm{~kg} / \mathrm{ha}$, either with single or split application, yields were almost identical $(6,249$ and $6,292 \mathrm{~kg} / \mathrm{ha})$. When the $\mathrm{N}$ level was increased to 112 $\mathrm{kg} / \mathrm{ha}$, yields were also very similar $(6,884$ and $6,802 \mathrm{~kg} / \mathrm{ha})$ for both application methods. No differences in yield attributable to time of application were measured; overall mean yields for the trial were 6,266 and $6,285 \mathrm{~kg} / \mathrm{ha}$ with single and split application of the $\mathrm{N}$, respectively.

The Capó fertilizer-yield equation (3) was applied to data from treatments $1(0 \mathrm{~N})$ to 6. 
TABle 2.-Effect of time and rate of $N$ fertilization on leaf content of $N, P, K, C a, M g$, and $M n$ in sorghum DeKalb BR-63 grown at Isabela, Puerto Rico

\begin{tabular}{|c|c|c|c|c|c|c|c|c|}
\hline \multicolumn{3}{|c|}{$\mathrm{N}$ treatment } & \multicolumn{6}{|c|}{ Leaf content } \\
\hline Application & No. & Rate & $\mathrm{N}$ & $\mathrm{P}$ & $\mathrm{K}$ & $\mathrm{Ca}$ & $\mathrm{Mg}$ & $\mathrm{Mn}$ \\
\hline & & $\mathrm{Kg} / \mathrm{ha}$ & & & $\%$ & & & $p / m$ \\
\hline None & 1 & 0 & $2.82 \mathrm{c}^{\prime \prime}$ & $0.40 \mathrm{~d}$ & $2.98 \mathrm{~cd}$ & $0.46 \mathrm{ab}$ & $0.25 \mathrm{a}$ & $176 \mathrm{~b}$ \\
\hline \multirow[t]{5}{*}{ All at planting } & 2 & 56 & $3.41 \mathrm{~b}$ & $.43 \mathrm{bcd}$ & $3.17 \mathrm{abcd}$ & $.47 \mathrm{a}$ & $.25 \mathrm{a}$ & $184 \mathrm{~b}$ \\
\hline & 3 & 112 & 3.93 a & .45 abcd & $3.00 \mathrm{bcd}$ & $.44 \mathrm{ab}$ & $.26 \mathrm{a}$ & $263 \mathrm{ab}$ \\
\hline & 4 & 168 & $3.80 \mathrm{ab}$ & $.42 \mathrm{~cd}$ & $3.14 \mathrm{abcd}$ & $.44 \mathrm{ab}$ & $.24 \mathrm{a}$ & $294 \mathrm{ab}$ \\
\hline & 5 & 224 & $3.67 \mathrm{ab}$ & .45 abcd & $3.20 \mathrm{abcd}$ & $.48 \mathrm{a}$ & $.25 \mathrm{a}$ & $265 \mathrm{ab}$ \\
\hline & 6 & 280 & $4.25 \mathrm{a}$ & .44 abcd & $3.34 \mathrm{ab}$ & $.35 \mathrm{c}$ & $.23 \mathrm{a}$ & 350 a \\
\hline Half at planting; half & 7 & 56 & $3.71 \mathrm{ab}$ & $.41 \mathrm{~d}$ & $2.89 \mathrm{~cd}$ & $.45 \mathrm{ab}$ & $.26 \mathrm{a}$ & $242 a b$ \\
\hline \multirow[t]{4}{*}{30 days later } & 8 & 112 & $3.65 \mathrm{ab}$ & $.47 \mathrm{abc}$ & $3.21 \mathrm{abcd}$ & $.49 \mathrm{a}$ & $.26 \mathrm{a}$ & 199 b \\
\hline & 9 & 168 & $3.76 \mathrm{ab}$ & $.48 \mathrm{ab}$ & $3.45 \mathrm{a}$ & $.49 \mathrm{a}$ & $.26 \mathrm{a}$ & $269 \mathrm{ab}$ \\
\hline & 10 & 224 & $4.13 \mathrm{a}$ & $.49 \mathrm{a}$ & $3.08 \mathrm{bcd}$ & $.49 \mathrm{a}$ & $.26 \mathrm{a}$ & $245 \mathrm{ab}$ \\
\hline & 11 & 280 & $4.00 \mathrm{a}$ & $.47 \mathrm{abc}$ & $3.24 \mathrm{abc}$ & $.43 \mathrm{ab}$ & $.25 \mathrm{a}$ & 192 b \\
\hline
\end{tabular}

'Means in columns followed by one or more letters in common do not differ significantly at the $5 \%$ level according to Duncan's multiple range test. 
TABLE 3.-Effect of time and rate of $N$ fertilization on days to midflower (MF), number of heads/plot (H/p), threshing percentage (TP), weight of 25 heads, grain crude protein (CP) content, and grain yield (GY) of DeKalb BR-63 hybrid sorghum grown at Isabela, Puerto Rico

\begin{tabular}{|c|c|c|c|c|c|c|c|c|}
\hline \multicolumn{3}{|c|}{$\mathrm{N}$ treatment } & \multicolumn{6}{|c|}{ Characteristic } \\
\hline Application & No. & Rate & MF & $\mathrm{H} / \mathrm{p}$ & $\mathrm{TP}$ & $\begin{array}{l}\text { Weight of } \\
25 \text { heads }\end{array}$ & $\begin{array}{c}\text { Grain } \\
\text { CP }\end{array}$ & GY \\
\hline & & $K g / h a$ & Days & No & $\%$ & $G$ & $\%$ & $K g / h a$ \\
\hline None & 1 & 0 & $75.1 \mathrm{a}^{\prime \prime}$ & $97.5 \mathrm{ab}$ & $72.6 \mathrm{a}$ & $805 \mathrm{~b}$ & $10.40 \mathrm{c}$ & $4,504 \mathrm{~b}$ \\
\hline \multirow[t]{5}{*}{ All at planting } & 2 & 56 & $69.1 \mathrm{~b}$ & $102.1 \mathrm{ab}$ & $74.4 \mathrm{a}$ & $942 \mathrm{ab}$ & $11.38 \mathrm{c}$ & 6,250 a \\
\hline & 3 & 112 & $66.8 \mathrm{~b}$ & $104.2 \mathrm{ab}$ & $.74 .2 \mathrm{a}$ & $1,109 \mathrm{a}$ & $10.99 \mathrm{c}$ & $6,884 a$ \\
\hline & 4 & 168 & $69.8 \mathrm{~b}$ & $91.3 \mathrm{ab}$ & $71.3 \mathrm{a}$ & $1,025 \mathrm{ab}$ & $11.07 \mathrm{c}$ & $5,764 \mathrm{a}$ \\
\hline & 5 & 224 & $68.8 \mathrm{~b}$ & $99.1 \mathrm{ab}$ & $70.0 \mathrm{a}$ & $1,004 \mathrm{ab}$ & $11.76 \mathrm{bc}$ & $6,103 a$ \\
\hline & 6 & 280 & $68.7 \mathrm{~b}$ & $102.3 \mathrm{ab}$ & $72.2 \mathrm{a}$ & $1,010 a b$ & $11.80 \mathrm{bc}$ & $6,529 \mathrm{a}$ \\
\hline Half at planting; half & 7 & 56 & $69.9 \mathrm{~b}$ & $99.7 \mathrm{ab}$ & $72.7 \mathrm{a}$ & $1,089 \mathrm{a}$ & $10.29 \mathrm{c}$ & $6,292 \mathrm{a}$ \\
\hline \multirow[t]{4}{*}{30 days later } & 8 & 112 & $69.7 \mathrm{~b}$ & $101.7 \mathrm{ab}$ & $73.7 \mathrm{a}$ & $1,027 \mathrm{ab}$ & $10.49 \mathrm{c}$ & $6,802 \mathrm{a}$ \\
\hline & 9 & 168 & $67.6 \mathrm{~b}$ & $110.8 \mathrm{a}$ & $73.5 \mathrm{a}$ & $1,116 \mathrm{a}$ & $12.04 \mathrm{abc}$ & $6,736 \mathrm{a}$ \\
\hline & 10 & 224 & $70.2 \mathrm{~b}$ & $98.5 \mathrm{ab}$ & $71.4 \mathrm{a}$ & $980 \mathrm{ab}$ & $13.23 \mathrm{ab}$ & $5,760 \mathrm{a}$ \\
\hline & 11. & 280 & $67.3 \mathrm{~b}$ & $86.1 \mathrm{~b}$ & $71.2 \mathrm{a}$ & $1,043 \mathrm{ab}$ & $13.63 \mathrm{a}$ & $5,828 \mathrm{a}$ \\
\hline
\end{tabular}

'Means in columns followed by one or more letters in common do not differ significantly at the $5 \%$ level according to Duncan's multiple range test. 
The equation developed is as follows:

$$
Y=\frac{A}{1+B\left(X-C^{2}\right)}
$$

where, $Y=$ yield ( $\mathrm{kg} / \mathrm{ha}) ; A=$ the maximum yield ( $\mathrm{kg} / \mathrm{ha}$ ) obtainable in the given field with optimum fertilizer application; $B=$ scale factor related to the independent variable; $C=$ the optimum fertilizer application ( $\mathrm{kg} / \mathrm{ha}$ ) for crop yield under treatment conditions; and $X=$ amount of $\mathrm{N}$ applied (kg/ha).

Table 4 shows the results of fitting the Capó fertilizer-yield equation to the data from the single-application $\mathrm{N}$ treatments (all at planting). The statistics of the equation show a fairly good fit of the curve, with a coefficient of determination of 0.45 . Therefore, if available $\mathrm{N}$ in the soil can be estimated, the equation could, to some extent, be used to predict

TABLE 4.-Results obtained from fitting the Capo fertilizer-yield equation to date from single-application treatments in an experiment with sorghum in an Oxisol

\begin{tabular}{rccc} 
N rate & $\begin{array}{c}\text { Adjusted mean } \\
\text { grain yields }\end{array}$ & $\begin{array}{c}\text { Grain yields } \\
\text { estimated from } \\
\text { equation }\end{array}$ & $\begin{array}{c}\text { Statistics of } \\
\text { fitted equation }\end{array}$ \\
\hline 0 & $\mathrm{Kg} / \mathrm{ha}$ & & $\mathrm{A}=6487$ \\
56 & 4,504 & 5,104 & $\mathrm{~B}=0.011$ \\
112 & 6,250 & 5,709 & $\mathrm{C}=211.73$ \\
168 & 6,884 & 6,192 & $\mathrm{CD}^{1}=0.453$ \\
224 & 5,764 & 6,458 & \\
280 & 6,103 & 6,441 & \\
\hline
\end{tabular}

${ }^{1} \mathrm{CD}=$ coefficient of determination.

grain sorghum yields from the amount of $\mathrm{N}$ fertilizer applied, within the range tested in this experiment. Near maximum yields (almost 90\%) are possible with applications of fertilizer $\mathrm{N}$ at only $56 \mathrm{~kg} / \mathrm{ha}$.

Green weight of stover (GW) varied from $13,816 \mathrm{~kg} / \mathrm{ha}$ with treatment $1(0 \mathrm{~N})$ to $16,035,14,171$, and $15,303 \mathrm{~kg} / \mathrm{ha}$ with single-application $\mathrm{N}$ treatments 3,5 , and 6 , respectively (table 5 ), but mean differences were not significant. In contrast, the GW decreased with all split application treatments except 7 and 9 . Dry weight of stover was generally lower with $\mathrm{N}$ application than without. The $\mathrm{N}$ content of grain ranged from 75 to $129 \mathrm{~kg} / \mathrm{ha}$; the former value (for $0 \mathrm{~N}$ ) was significantly lower than all other values (with fertilizer $\mathrm{N}$ ). The $\mathrm{N}$ content of stover ranged from 32 to $40 \mathrm{~kg} / \mathrm{ha}$, but mean treatment differences were not significant. The best apparent fertilizer $\mathrm{N}$ recovery, $71 \%$, was with $\mathrm{N}$ at $56 \mathrm{~kg} / \mathrm{ha}$, all applied at planting; the next best recovery was $57 \%$, with $\mathrm{N}$ at $56 \mathrm{~kg} / \mathrm{ha}$ in split applications. The apparent fertilizer $\mathrm{N}$ recovery generally de- 
TABLE 5.-Effect of time and rate of $N$ fertilization on stover yield and $N$ content in grain and stover of DeKalb hybrid sorghum grown at Isabela, Puerto Rico

\begin{tabular}{|c|c|c|c|c|c|c|c|c|}
\hline \multicolumn{3}{|c|}{$\mathrm{N}$ treatment } & \multicolumn{2}{|c|}{ Stover yield } & \multicolumn{4}{|c|}{$\mathrm{N}$ content } \\
\hline \multirow[t]{2}{*}{ Application } & No. & Rate & $\begin{array}{l}\text { Green } \\
\text { weight }\end{array}$ & $\begin{array}{c}\text { Dry } \\
\text { weight }\end{array}$ & Grain & Stover & $\begin{array}{l}\text { Gran } \\
\text { plus } \\
\text { stover }\end{array}$ & $\begin{array}{l}\text { Apparent } \\
\text { fertilizer } \\
\text { N recovery }\end{array}$ \\
\hline & & & & \multicolumn{2}{|c|}{$\mathrm{Kg} / \mathrm{ha}$} & \multicolumn{3}{|c|}{$\%$} \\
\hline None & 1 & 0 & $13,816 \mathrm{ab}^{1}$ & $3,511 \mathrm{ab}$ & $75 \mathrm{~b}$ & $36 \mathrm{a}$ & 110 & - \\
\hline \multirow[t]{5}{*}{ All at planting } & 2 & 56 & $13,594 \mathrm{ab}$ & $3,391 \mathrm{ab}$ & $114 \mathrm{a}$ & $36 \mathrm{a}$ & 150 & 71 \\
\hline & 3 & 112 & 16,035 a & $3,687 \mathrm{ab}$ & $121 \mathrm{a}$ & 34 a & 155 & 40 \\
\hline & 4 & 168 & $13,565 \mathrm{ab}$ & $3,259 \mathrm{ab}$ & $103 \mathrm{a}$ & 33 a & 136 & 15 \\
\hline & 5 & 224 & $14,171 \mathrm{ab}$ & $3,272 \mathrm{ab}$ & $114 \mathrm{a}$ & 32 a & 146 & 16 \\
\hline & 6 & 280 & $15,503 \mathrm{a}$ & $3,533 \mathrm{ab}$ & $122 \mathrm{a}$ & $34 \mathrm{a}$ & 156 & 16 \\
\hline Half at planting; half & 7 & 56 & $15,579 \mathrm{a}$ & $3,474 \mathrm{ab}$ & $104 \mathrm{a}$ & $38 \mathrm{a}$ & 142 & 57 \\
\hline \multirow[t]{4}{*}{30 days later } & 8 & 112 & $13,681 \mathrm{ab}$ & $3,443 \mathrm{ab}$ & $114 \mathrm{a}$ & 38 a & 152 & 38 \\
\hline & 9 & 168 & $15,635 \mathrm{a}$ & $3,840 \mathrm{a}$ & $129 \mathrm{a}$ & $40 \mathrm{a}$ & 169 & 35 \\
\hline & 10 & 224 & $11,564 \mathrm{~b}$ & $3,072 \mathrm{ab}$ & $121 \mathrm{a}$ & 35 a & 156 & 21 \\
\hline & 11 & 280 & $12,598 \mathrm{ab}$ & $2,864 \mathrm{~b}$ & $127 \mathrm{a}$ & $32 \mathrm{a}$ & 159 & 18 \\
\hline
\end{tabular}

'Means in columns followed by one or more letters in common do not differ significantly at the 5\% level according to Duncan's multiple range test.

${ }^{2} \mathrm{~N}$ content of fertilized plant minus $\mathrm{N}$ content of check plant/ $\mathrm{N}$ fertilizer applied. 
creased as the $\mathrm{N}$ fertilizer levels increased, both in single (planting) and split applications.

The results of this study suggest that crude protein levels in the grain are higher with split applications of $280 \mathrm{~kg} / \mathrm{ha}$ of $\mathrm{N}$ than with a single $\mathrm{N}$ application. Also, near maximum yields were obtained with application of $\mathrm{N}$ at $56 \mathrm{~kg} / \mathrm{ha}$. Use of this low rate could result in substantial savings in fertilizer costs.

\section{RESUMEN}

En un Oxisol en la zona noroeste de Puerto Rico se realizó un experimento para evaluar el efecto de varios niveles de $\mathrm{N}$ y épocas de aplicación sobre los rendimientos de sorgo de grano, la absorción de nutrimentos y otros índices. El suelo tenía 30\% de saturación de $\mathrm{Al}$ y niveles de $\mathrm{Ca}, \mathrm{Mg}, \mathrm{K}$ relativamente bajos. El contenido en $\mathrm{N}$ del tejido foliar fue significativamente más bajo en plantas que no recibieron aplicaciones de N. Se observaron diferencias significativas en el contenido en K, Ca y Mn de las hojas, pero no siguieron un patrón definido y consistente. La granazón se atrasó significativamente en las plantas que no recibieron $\mathrm{N}$, pero el porcentaje en grano trillado (threshing \%) no se afectó. Aplicaciones divididas de $\mathrm{N}$ produjeron los niveles más elevados de proteína bruta en el grano. La ecuación abono-rendimiento desarrollada por Capó, se ajusta bastante bien a los datos de rendimiento de grano y permite predecirlo con bastante precisión a base del $\mathrm{N}$ aplicado. Los datos demuestran que es posible alcanzar casi el máximo de rendimiento con aplicaciones de $56 \mathrm{~kg} / \mathrm{ha}$ de $\mathrm{N}$.

\section{LITERATURE CITED}

1. Badillo-Feliciano, J., and Lugo-López, M. A., 1976. Effect of four levels of N, P, K, and micronutrients on sweetpotato yields in an Oxisol, J. Agric. Univ. P.R. 60 (4): 597-605.

2. Black, C. A., (Ed), 1965. Methods of Soil Analysis, Part 2, Chemical and Microbiological Properties, No. 9 in the series Agronomy, Am. Soc. Agron.

3. Capo, B. G., 1967. Additional evidence on the applicability of the new fertilizer-yield relation, J. Agric. Univ. P.R, 51(2): 97-120.

4. Fiske, C. H., and Subbarow, Y., 1925. The colorimetric determination of phosphorus, J. Biol. Chem. 66 (2): 375-400.

5. Fox, R. H., Talleyrand, H., and Bouldin, D. R., 1974. Nitrogen fertilization of corn and sorghum grown in Oxisols and Ultisols in Puerto Rico, Agron. J. 66: 534-40.

6. Lugo-López, M. A., and Rivera, L. H., 1976. Taxonomic classification of the soils of Puerto Rico, Agric. Exp. Stn., Univ. P.R., Bull. 245.

7. Maunder, B. A., 1975. Potential for sorghum production in Latin America-Commercial Point of View, Int. Sorghum Workshop, Mayagüez Campus, Univ. P.R., January $7-11$.

8. Samuels, G., Alers-Alers, S., and Riera, A., 1955. The method of foliar diagnosis as applied to sugarcane, Agric. Exp. Stn., Univ. P.R., Bull. 123.

9. Talleyrand, H., Fox, R. H., and Lugo-López, M. A., 1976. Nitrogen fertilization of a high yielding white-kernel corn in Oxisols and Ultisols in Puerto Rico, J. Agric. Univ. P.R. 60(3): 336-43.

10. - and Lugo-López, M. A., 1976. Performance of high-yielding corn hybrids Pioneer X 306-B and Funk's G-795W at high levels of fertilization in the acid and relatively infertile soils (Ultisols and Oxisols) of Puerto Rico, J. Agric. Univ. P.R. 60(1): 132-4. 